\title{
ACCESSING ACADEMIC LANGUAGE: THE BENEFITS OF AN EXPLICIT STUDY OF LATIN AND GREEK ROOTS
}

\author{
Gail Solomons (University of Cape Town)
}

\section{Introduction}

Many students in South Africa are entering university linguistically underprepared to cope with the meta-language of academe. Reasons for this are proposed by Language Development staff in the Academic Development Programme at UCT (Thesen et al., 1997:1-2):

First, the language system, or code (in this case English, which is also the medium of instruction) can pose problems for students for whom it is not a main language. Second, the new formal register which students meet in the transition from school to university presents difficulties for almost all first time entering students. A third factor is previous educational experience. Students who have not had practice in the more abstract cognitively demanding tasks (in English or any other language) through which quality schooling prepares students for the transition to university, are at a disadvantage.

If students are disadvantaged for any one, or perhaps all, of the reasons mentioned above, how do they decipher the meaning in academic texts and write effectively in the academic register?

The meaning of 'meaning' and where meaning resides has always been contentious and continues to be debated by linguists and semanticists. Gee (1990:84) and Brumfit (1994:21-33) ${ }^{1}$ argue that words do not have fixed meanings, as found in the dictionary, but are always used in contexts. They find no sense in looking at words isolated from their contexts. As a strategy to understanding an academic text which contains a number of unfamiliar words and concepts, students may skip over unfamiliar words and rely upon context to give clues to meaning. They can use information from one level of understanding to compensate for a lack of competence in another. Another way of getting around gaps in their knowledge of language is to use a priori knowledge (Garnham, 1994:97-114). However, if context does not provide adequate clues to meaning or if students do not have the background knowledge or necessary cultural matrix required to decode the text, without word knowledge per se, text processing is difficult.

The importance of the word 'knowledge' is emphasized by Brown (1994:60), who suggests that lexical meaning is the sense attributed to items in the dictionary and that lexical and grammatical meaning are closely related because they are the "basic building blocks of meaning, what you need to get straight before you even get to the point of developing a misunderstanding". According to Cummins (1984:27), academic writing relies on "linguistic cues to meaning and thus successful interpretation of the message depends heavily on knowledge of the language itself".

$1 \quad$ See also Leech 1974, Crystal 1976, Adlam 1977, and Moon 1992 who support this view. 
Stubbs (1990: 558) supports this view, arguing that a high value is placed on the language in which knowledge is construed, and that those who cannot gain command of it remain outsiders. He stresses that written texts and writing have always been central to the Western educational system. Without adequate lexical resources to support their textual processing, students cannot read and write effectively in the academic discourse. Taylor et al. (1988:64) argue as follows: "Students' problems lie less in a simple ability to handle the surface forms of syntactic and other structures themselves than in an inability to control linguistic form in unfamiliar and intellectually taxing contexts of meaning."

Laufer (1992: 126-130) investigates how much lexis is necessary for reading comprehension in a second language. She finds that, in the interpretation of texts, students rely on word meaning first, then on knowledge of the subject and least of all on syntax. She contends that the nature of the reading threshold is largely lexical and that "reading comprehension at an academic level requires 95\% lexical coverage, i.e. knowledge of $95 \%$ of word tokens in any given text". ${ }^{2}$ Although her focus was on students for whom English was a second language, the need for a comprehensive vocabulary is important for all students.

To clarify the type of language that constitutes academic language, Ferguson (1959) coined the term 'diglossia'. This describes the existence of a dual lexicon in English and other languages: the High style $(\mathrm{H})$ and the Low style $(\mathrm{L}) . \mathrm{H}$ is essentially a literary language which is learned in formal education and used in academic writing, while $\mathrm{L}$ is the medium of ordinary conversation acquired from childhood or by immersion. The difference between the two styles is defined as the Latinate-Germanic split in the lexicon. ${ }^{3}$ Although English is a Germanic language, the Classical languages have had a profound influence on the development of English vocabulary, particularly on academic vocabulary. The practice of freely incorporating words of Latin and Greek roots into English began centuries ago when Latin and Greek were considered the primary languages of the Church and scholarship. It continued through the Norman Conquest and the Renaissance and continues still today. Some words have been borrowed unchanged, others have been 'Anglicized' using English prefixes and suffixes, and thousands of new words have been coined using Latin or Greek roots and prefixes. Most of these words are formal, specialized and academic. It is estimated that while over $60 \%$ of all English words have Latin or Greek roots, in academic texts this figure rises to 90\% (Luschnig, 1982: 83-85).

Historically, Graeco-Latinate (G-L) words were introduced into academic English to label new knowledge areas and to give expression, with clarity and succinctness, to abstract thought. There are two kinds of academic, usually GraecoLatinate, words: those technical words pertinent to each discipline, and general academic vocabulary. Knowledge of both kinds of words is necessary but Laufer

2 To test whether a knowledge of Latin and Greek roots would improve the English vocabulary of second language speakers, Jo-Marie Claassen 1994: 7-9 conducted an experiment with Standard Eight (Grade 10) Xhosa-speaking pupils. The students participated in nine forty-minute lessons, in which approximately 50 Latin and Greek words were introduced. From these words the pupils were able to form triple that number of English words.

3 This is similar to the distinction made by Cummins 1984: 130-151 between Cognitive Academic Language Proficiency (CALP) and Basic Interpersonal Skills (BICS). 
(1992:130) cautions that it is the general rather than the technical language that is problematic. Along with the common core basic meaning in these general academic words, metaphors are embedded to give abstract meanings (Corson, 1981:180). In students' comprehension of academic texts it is the abstract quality of written language which causes the most difficulty.

Corson (1981: 232) investigated the semantic contribution of words to language, focusing on words of Latin and Greek origin. He proposed that GraecoLatinate (G-L) words are used so frequently in academic texts because they have the "capacity for conveying shades of meaning, which adds succinctness and precision, not redundancy" to texts. They are not easily defined by means of a one-word synonym. They are semantically complex. To demonstrate this, he devised a way of measuring the semantic complexity of written and oral English (1982: 1-10). He carried out a frequency count of G-L words in different varieties of written English. He used a representative text for different literary areas, analysing random passages of 100 consecutive words for their G-L content (articles and prepositions were excluded). He found that there is a clear connection between the degree of difficulty of the subject matter and the percentage incidence of G-L lexis in that subject matter. The frequency level was highest in academic disciplines in which technical vocabulary and abstract concepts were prolific, descending to newspapers of varying levels of seriousness and then to children's fiction. ${ }^{4} \mathrm{He}$ did a further study of seven educationally linked knowledge categories, listed below, calculating the percentage $\mathrm{G}-\mathrm{L}$ for each. The mean G-L percentage incidence was 74\%, confirming the link of G-L lexis with academic texts.

\begin{tabular}{|l|c|c|c|}
\hline 1 & Logic and Maths & (800 words) & $67 \%$ \\
\hline 2 & Physical Sciences & (2 200 words) & $75 \%$ \\
\hline 3 & Human Sciences & (3 200 words) & $71 \%$ \\
\hline 4 & Ethics & (400 words) & $70 \%$ \\
\hline 5 & Aesthetics & (400 words) & $86 \%$ \\
\hline 6 & Religion & (300 words) & $67 \%$ \\
\hline 7 & Philosophy & (800 words) & $80 \%$ \\
\hline
\end{tabular}

He concluded that, since G-L words abound in academic texts, a lexical barrier separates students who possess a G-L vocabulary and those who do not.

Corson suggests that if students can understand the core common meaning of a word by looking at the root, its essence, then they will find it easier to extract the metaphor embedded in its components, and this will give a clue to the word's abstract use in a particular context. Beyond that, they will be able to use the word themselves they will own the word because they understand its elemental meaning.

Many studies have been done, especially in America, on the effects of a knowledge of Latin on reading and vocabulary skills - for example the FLES

$4 \quad$ For example (G-L lexemes are expressed as a percentage): Philosophy 40\%; Sociology 38\%; Psychology 32\%; Mathematics 29\%; Newspaper A editorial 24\%; Newspaper B editorial 18\%; Newspaper C courtroom story 4\%; children's fiction 7-8 years 3\%; children's fiction 5-6 years $0 \%$. 
programme which started in the 1970s, ${ }^{5}$ and, of course, the Scholastic Aptitude Tests (SAT). Studies conducted by the Educational Testing Service show that Latin students consistently outperform all other students on the verbal portion of the SATs. These statistics were published by Bolchazy-Carducci Publishers in 2006:

\begin{tabular}{|l|c|c|c|c|c|c|}
\hline Year & $\mathbf{2 0 0 0}$ & $\mathbf{2 0 0 1}$ & $\mathbf{2 0 0 2}$ & $\mathbf{2 0 0 3}$ & $\mathbf{2 0 0 4}$ & $\mathbf{2 0 0 5}$ \\
\hline & & & & & & \\
\hline Latin & $\mathbf{6 6 5}$ & $\mathbf{6 6 5}$ & $\mathbf{6 6 6}$ & $\mathbf{6 7 2}$ & $\mathbf{6 7 4}$ & $\mathbf{6 8 1}$ \\
\hline All students & $\mathbf{5 0 5}$ & $\mathbf{5 0 6}$ & $\mathbf{5 0 4}$ & $\mathbf{5 0 7}$ & $\mathbf{5 0 8}$ & $\mathbf{5 0 8}$ \\
\hline French & 636 & 633 & 637 & 638 & 642 & 643 \\
\hline Hebrew & 623 & 628 & 629 & 628 & 630 & 620 \\
\hline German & 621 & 625 & 622 & 626 & 627 & 637 \\
\hline Spanish & 589 & 583 & 581 & 575 & 575 & 573 \\
\hline
\end{tabular}

To investigate whether an explicit study of Latin and Greek roots does assist students in accessing academic language, I conducted a quantitative and a qualitative study using both current students and former students of the etymology (Word Power) course at UCT.

The quantitative study was in the form of:

1. A vocabulary test ${ }^{6}$ that was administered in the first week of the second semester 2006 to a group of first year students (35) new to the course. The test sheets were retained and then the same students re-wrote the test at the end of the semester.

5 With the influx of immigrants for whom English was a second language, there was growing concern amongst educators about literacy standards in America. The FLES (Foreign Languages in Elementary Schools) programmes were introduced in inner-city schools. Students in the Latin FLES programmes achieved better results on tests of reading and vocabulary skills than other students on the FLES programmes. Claassen 1979: 70-86, citing le Bovit, reported as follows:

The Division of Research and Evaluation of the Public Schools of the District of Columbia in 1970-71 carried out an independent, statistically acceptable survey of English reading and vocabulary skills, pre and post a 7 month period, on 223 pupils in their first year of FLES Latin, 249 pupils in their third year of Spanish and French, and a control group of 650 pupils with no foreign language training. The Latin group, having initially been rejected as subjects for the modern languages, started out in October with the lowest reading scores and ended up with the highest, not only surpassing the 'no foreign language' pupils, but also slightly exceeding the Spanish and French FLES pupils who had almost completed their third year of a foreign language.

6 The questions were as follows:
A. Circle the word which best fits the definition.
B. Indicate whether the following are synonyms or antonyms.
C. What do the following love, fear or study?
D. What number is hidden in the following words?
E. Give the meaning of only the root in the following words. 
2. The same vocabulary test was administered to a group of third year students (30) who had studied the course two years previously in 2004 (former Word Power students).

3. The same test was administered to a group of third year students (30) who had not studied the course. Each of the former Word Power students who volunteered to write the test was asked to bring along a friend who was in the same year of study but who had not studied Word Power (non-Word Power students).

The average scores were as follows:

\section{First-year students 2006}

Test 1: 30,2\%

\section{Test 2: 68,8\%}

This improvement was to be expected once the students had studied the course for a full semester. The next test was particularly interesting. It was written by two groups of third-year students - former Word Power and non Word Power students. A comparison between the results of the first test written by the first-year students who had just started university and the results of the test written by the third year nonWord Power students demonstrates that the vocabulary of students improves during their years at university as a result of their exposure to academic reading and practice in academic writing. However, a comparison between the results of the third year former Word Power students and the third year non-Word Power students shows that studying G-L roots increases their vocabulary dramatically.

\section{Former Word Power students 2004}

$75,3 \%$

\section{Non-Word Power students (third-year status)}

\section{$54,3 \%$}

The qualitative study took the form of a questionnaire which required ratings as well as comments, if the student wished to make any.

The questionnaire asked the 2004 students to evaluate the statements using the following rating system:

$1=$ not at all $; 2=$ a little; $3=$ moderately $; 4$ = significantly; $5=$ enormously 
The questions and results are as follows:

Subsequent to my semester of studying Word Power, I have found that:

1. My vocabulary has improved.

\begin{tabular}{|l|c|c|c|c|c|}
\hline Rating: & 1 & 2 & 3 & 4 & 5 \\
\hline & & & & & \\
\hline Responses: & 0 & 2 & 5 & $\mathbf{1 6}$ & 7 \\
\hline
\end{tabular}

2. My spelling has improved.

\begin{tabular}{|l|c|c|c|c|c|}
\hline Rating: & 1 & 2 & 3 & 4 & 5 \\
\hline & & & & & \\
\hline Responses: & 0 & 8 & 8 & $\mathbf{1 0}$ & 4 \\
\hline
\end{tabular}

3. My use of English has improved.

\begin{tabular}{|l|c|c|c|c|c|}
\hline Rating: & 1 & 2 & 3 & 4 & 5 \\
\hline & & & & & \\
\hline Responses: & 0 & 2 & $\mathbf{1 2}$ & $\mathbf{1 0}$ & 6 \\
\hline
\end{tabular}

4. My ability to work out meanings of new words encountered in my reading has improved.

\begin{tabular}{|l|c|c|c|c|c|}
\hline Rating: & 1 & 2 & 3 & 4 & 5 \\
\hline & & & & & \\
\hline Responses: & 0 & 2 & 2 & $\mathbf{1 6}$ & $\mathbf{1 0}$ \\
\hline
\end{tabular}

5. Word Power has encouraged my interest in words and their origins.

\begin{tabular}{|l|c|c|c|c|c|}
\hline Rating: & 1 & 2 & 3 & 4 & 5 \\
\hline & & & & & \\
\hline Responses: & 0 & 0 & 0 & $\mathbf{1 2}$ & $\mathbf{1 8}$ \\
\hline
\end{tabular}


Section B: Comments, if you so wish.

A few of the comments:

It has improved my written English a lot because now I can understand academic words.

Though there is plenty I have forgotten, certain things, such as the meanings of prefixes etc., have stuck in my mind and have enhanced my understanding of language. My abilities in English were good to begin with but they were definitely improved after completing the course.

Word Power has really helped me to understand more concepts and words that I encounter in my readings. I can easily understand words just by looking at their roots. Also I found myself using some vocabulary that I did not think that I would be able to use at this stage.

It was interesting to study Word Power when specializing in the Sciences. Inarticulate writing is a definite problem in the world of scientific publishing, and to this effect I think Word Power has gone a long way toward improving my ability to write clear, eloquent and interesting essays.

Word Power has helped both in academic and general life - mainly with feeling confident to decipher 'cryptic' words more confidently.

If I don't understand a word, I try to dissect it and remember what I learnt.

Participation in this test was voluntary and therefore, naturally, these would be students who enjoyed and absorbed what Word Power had to offer. Nevertheless their evaluation and comments were most gratifying. Almost all these students felt that Word Power had impacted on their academic language significantly, if not enormously, and all the students indicated an improvement in their linguistic competence. The benefits of their one semester study of G-L roots have remained with them as they have progressed in their academic careers.

Etymology courses began as a way of keeping Classics Departments alive in universities as a counter to the decline in the number of students studying Latin and Greek per se. However, the value of such courses extends beyond self-preservation: they have proved themselves worthy of their place in academe. Ellis (1994:51) argues that "to the extent that vocabulary acquisition is about meaning, it is an explicit learning process". I hope that the study described above has shown that an explicit study of Latin and Greek roots is of enormous benefit to students because it provides one of the most powerful tools fundamental to the acquisition of academic literacy: an understanding of words. 


\section{BIBLIOGRAPHY}

Adlam, D S 1977. Code in Context. London: Routledge \& Kegan.

Angelil-Carter, S \& M Paxton 1993. Overview of a developing theoretical framework for Language work in academic development at the University of Cape Town. Language in Academic Development at UCT, 4-10. ASP/AD: UCT.

Bolchazy-Carducci, 2006/05/03. http://www.bolchazy.com/al/latadv.htm.

Brown, G et al. 1994. Language and Understanding. Oxford: Oxford University Press.

Brumfit, C 1994. Understanding, Language, and Educational Processes. In Brown, G, Language and Understanding, 21-33. Oxford: Oxford University Press.

Claassen, J M 1979. Latin in American Elementary Schools. Akroterion, 24.3: 24-30.

Claassen, J M 1994. The Problems and Possibilities of Bilingualism in a Multicultural Society. $13^{\text {th }}$ ISSED Conference. Cape Town.

Corson, D J 1981. Social Class, the Semantic Barrier and Access to Curricula Knowledge. PhD dissertation. University of London.

Corson, D J 1982. The Graeco-Latin (G-L) Instrument: A New Measure of Semantic Complexity in Oral and Written English. Language and Speech, Vol. 25, Part 1, 1-10.

Crystal, D 1976. Child Language Learning and Linguistics - an overview for the teaching and therapeutic professions. London: Edward Arnold.

Cummins, J 1984. Language Proficiency, Bilingualism and Academic Achievement. In Allen, $\mathrm{P}$ and Swain, M, Language Issues and Educational Policies, 130-151. Pergamom Press in association with the British Council.

Ellis, N 1994. Consciousness in Second Language Learning. Psychological Perspectives on the Role of Conscious Processes in Vocabulary Acquisition. AILA Review 11: 51-56.

Ferguson, C 1959. Diglossia. Word, Volume 15, 435.

Garnham, A 1994. Psychological Processes and Understanding. In Brown, G at al, Language and Understanding. Oxford: Oxford University Press.

Gee, J 1990. Social Linguistics and Literacies: Ideology in Discourse. London: Falmer Press.

Laufer, B 1992. How much lexis is necessary for reading comprehension? In Arnaud, P \& Bejoint, H, 126-130. London: MacMillan.

Leech, G 1974. Semantics. London: Penguin.

Luschnig, C \& Luschnig, L J 1982. Etyma: An Introduction to Vocabulary Building from Latin and Greek. London: University Press of America.

Moon,R 1992. Textual Aspects of Fixed Expressions in Learner's Dictionaries. In Arnaud, P \& Bejoint, H, Vocabulary and Applied Linguistics, Chapter 2. London: MacMillan.

Stubbs, M 1990. Language in Education. An Encyclopaedia of Language. London: Routledge. 
Taylor, G et al. 1988. Literacy by Degrees. Milton Keynes: Open University Press.

Thesen, L et al. 1997. Language Development and Communication: Contributions to Academic Programmes. University of Cape Town Academic Development Programme. 